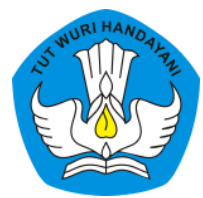

Page: 515-536

\title{
PENGEMBANGAN APLIKASI ANOLA BERBASIS ANDROID UNTUK PEMBELAJARAN ATLETIK NOMOR LARI JARAK PENDEK
}

\author{
Bambang Hariyanto \\ Sekolah Menengah Pertama Negeri 3 Bumijawa Kabupaten Tegal Jawa Tengah \\ Contributor Email: bahari1882@gmail.com
}

Published: Juli 30, 2020

Article Url: https:/ / ojsdikdas.kemdikbud.go.id/index.php/didaktika/article/view/150

\begin{abstract}
The product of the digital age advances is the existence of sophisticated devices such as smartphones, which are now an inseparable part of human life. This device makes all human activities become practical and fast. The development of the Athletics application Running Number abbreviated as ANOLA is one of the learning innovations. The purpose of this study is to describe the application development, practicality and effectiveness of android-based so that it can be used as a learning media for athletic material running number Method used is Design and Development $(D \mathcal{E} D)$ while the process of developing an ANOLA application uses the Analysys, Design, Development, Implementation, Implementation, Evaluation (ADDIE). The results of the study show that the practicality of ANOLA application shows the number 94.67\% (Very Practical), while the effectiveness test is 96\% (Very Effective). Feasibility test by media experts obtained $96.67 \%$ (Very Eligible). The results of the competency test through pre-test and post-test showed an increase in mastery learning in class $8 \mathrm{D}$ students by $53 \%$ in the realm of knowledge (KI.3) and by $23 \%$ in the realm of skills (KI. 4).
\end{abstract}

Keywords: Application Development, Android, Athletic Learning. 


\begin{abstract}
Abstrak
Produk kemajuan era digital adanya perangkat canggih berupa telepon pintar (smartphone), yang saat ini menjadi bagian yang tidak terpisahkan dari kehidupan manusia. Perangkat ini menjadikan segala aktivitas manusia menjadi praktis dan cepat. Pengembangan aplikasi Atletik Nomor Lari disingkat ANOLA adalah salah satu inovasi pembelajaran. Tujuan penelitian ini yaitumendeskripsikan pengembangan aplikasi, kepraktisan dan keefektifan berbasis android agar dapat digunakan sebagai media pembelajaran materi atletik nomor lari Metode yang digunakan yaitu Design and Development $(D \mathcal{E} D)$ sedangkan proses pengembangan aplikasi ANOLA menggunakan model Analisys, Design, Development, Implementation, Evaluation (ADDIE).Hasil penelitian bahwauji kepraktisan aplikasi ANOLA menunjukan angka 94,67\% (Sangat Praktis), sedangkan uji keefektifan sebesar 96\% (Sangat Efektif). Uji kelayakan oleh ahli media diperoleh angka 96,67\% (Sangat Layak). Hasil uji kompetensi melalui pre test dan post test menunjukan peningkatan ketuntasan belajar klasikal peserta didik kelas $8 \mathrm{D}$ sebesar $53 \%$ pada ranah pengetahuan (KI.3) dan sebesar $23 \%$ pada ranah keterampilan (KI. 4).
\end{abstract}

Kata Kunci: Pengembangan Aplikasi, Android, Pembelajaran Atletik.

\title{
A. Pendahuluan
}

Generasi saat ini dikenal dengan istilah generasi milenial, yaitu generasi abad 21 yang lahir mulai tahun 1970-2015. Generasi milenial akan hidup di era digital, dimana terjadi perubahan besar dalam berbagai sendi kehidupan termasuk bidang pendidikan. Perubahan besar dikenal dengan istilah revolusi industri 4.0. Pada era ini berkomunikasi dengan orang lain dibelahan bumi manapun selama terkoneksi dengan jaringan internet akan memungkinkan terjadinya pertukaran budaya, pengetahuan dan teknologi.

Salah satu produk dari kemajuan era digital adalah adanya perangkat canggih berupa telepon pintar (smartphone) yang saat ini menjadi bagian yang tidak terpisahkan dari kehidupan manusia. Perangkat ini menjadikan segala aktivitas manusia menjadi praktis dan cepat. Ketersediaan berbagai aplikasi yang menarik dan canggih di dalam smartphone menjadikan seseorang dapat bertahan lama saat menggunakan perangkat ini. Guna mendapatkan pengetahuan sesuai dengan apa yang 
ingin dipelajari hanya cukup dengan menuliskan kata kunci tertentu, bahkan saat ini menjadi sarana untuk pembelajaran jarak jauh melalui aplikasi yang didesain khusus untuk kegiatan belajar secara daring.

Jika melihatpeserta didik kelas 8 di SMP Negeri 3 Bumijawa menunjukan bahwa peserta didik yang memiliki perangkat smartphone berbasis android seringmembukamedia sosial berupa Facebook, Games, Whatsapp dan Youtube. Sehingga agar pemanfaatan teknologi informasi lebih bermanfaat perlu ada fasilitas baru yang dapat diakses untukpembelajaran yang dapatmengurangi dampak negatif media sosial.

Aktivitas pembelajaran PJOK di SMP Negeri 3 Bumijawa lebih didominasi pada kegiatan praktik keterampilan, sebagaimana karakteristik mata pelajaran PJOK yang bertujuan agar peserta didik melakukan aktivitas fisik untuk kebugaran jasmaninya. Sesuai dengan kurikulum yang ditetapkan oleh pemerintah, waktu yang tersedia untuk pembelajaran PJOK yaitu tiga jam pelajaran setiap minggunya, di dalam proses pembelajarannya harus mencakupbeberapakompetensiyaitu a). KI. 1 (kompetensi spiritual); b). KI. 2 (kompetensi sosial); c). KI. 3 (kompetensi pengetahuan); dan d) KI. 4 (kompetensi keterampilan).

Pada aktivitas pembelajaran PJOK di kelas 8 khususnya materi atletik nomor lari, kompetensi keterampilan menjadi komponen yang membutuhkan waktu pembelajaran lebih lama dibandingan kompetensi pengetahuan, hal ini dikarenakan kemampuan kinestetik motorik peserta didik berbeda-beda, sehingga perlu aktivitas gerak yang berulang agar dapat mencapai standar kompetensi yang diharapkan.

Penggunaan media buku teks dengan materi yang terbatas serta metode ceramah yang dilakukan guru ternyata kurang menarik bagi peserta didik, sehingga perlu dikembangankan media pembelajaran lain yang lebih menarik dan dapat digunakan setiap saat oleh peserta didik dalam mempelajari materi pembelajaran. Pada awal pembelajaran, guru memberikan tugas kepada peserta didik untuk membaca materi pada buku paket PJOK dan saat kegiatan praktik, guru juga menerangkan teori 
aktivitas atletik nomor lari jarak pendek, akan tetapi dari hasil evaluasi pembelajaran tentang materi pengetahuan ternyata rata-rata peserta didik kurang menguasai materi atletik nomor lari jarak pendek.

Pengembangan aplikasi pembelajaran berbasis android sangat sesuai dengan karakteristik peserta didik abad 21 karena di era revolusi industri 4.0 mengharuskan peserta didik memiliki kecakapan hidup seperti sikap kritis, kreatif, komunikasi, berkolaborasi, literasi informasi, literasi media, literasi teknologi, produktif dan kecakapan lain yang dibutuhkan untuk kehidupan mereka.

Pengembangan aplikasi Atletik Nomor Lari disingkat ANOLA adalah salah satu inovasi pembelajaran yang dapatdilakukan dalam rangka menambah media pembelajaran peserta didik yang relevan dengan perkembangan zaman. Aplikasi ANOLA dapat digunakan pada sistem operasi android smartphone yang saat ini paling banyak digunakan oleh masyarakat, pada aplikasi ini berisi materi pembelajaran atletik yang sesuai dengan kurikulum 2013.

Istilah aplikasi dalam bidang teknologi informasi adalah perangkat lunak (software) yang dapat dijalankan sesuai dengan perintah penggunanya. Aplikasi dapat dijalankan pada berbagai sistem operasi seperti android, IOS dan Symbian. Setiap aplikasi dirancang agar dapat digunakan sesuai dengan tujuan dan pada umumnya memiliki fasilitas yang sangat membantu berbagai pekerjaan manusia. Penggunaan aplikasi dalam dunia pendidikan sudah dimulai sejak abad 20, ketika itu perangkat yang digunakan masih cukup sederhana. Memasuki era revolusi industri $4.0 \mathrm{ini}$, penggunaan aplikasi yang mendukung proses pembelajaran mulai berkembang dengan pesat, aplikasi berbasis android menjadi salah satu perangkat lunak yang saat ini cukup banyak dimanfaatkan dalam pendidikan.

Menurut Khanna \& Singh (2016) android adalah platform perangkat lunak dan sistem operasi untuk perangkat selular berbasis Linux. Android menjadi salah satu sistem operasi yang paling banyak digunakan pada smartphone saat ini, lebih dari $90 \%$ pasar smartphone di Indonesia menggunakan android sebagai sistem operasinya 
(www.jabar.tribunnews.com). Pada awalnya android adalah sebuah perusahan bernama Android, Inc. yang didirikan oleh Palo Alto di California tahun 2003. Kemudian pada tahun 2005 menjadi anak perusahaan Google. Setelah menjadi salah satu bagian dari Google, android terus berkembang dan mengalami beberapa perbaikan dan penambahan fitur baru agar lebih optimal.

Tokoh pendidikan modern Edgar Dale memunculkan sebuah teori Cone Experience (kerucut pengalaman) atau dikenal dengan piramida pembelajaran yang mengelompokan aktivitas belajar dan persentase yang diingat serta keterlibatan dalam pembelajaran. Kegiatan pengalaman belajar menurut Dale (Sari, 2019) 10\% yang diingat dari membaca, 20\% dari mendengarkan, 30\% dari melihat gambar dan video, $50 \%$ dari diskusi, $70 \%$ dari presentasi dan $90 \%$ dari pratik langsung. Berdasarkan teori tersebut maka peran media pembelajaran yang menarik yang berisi materi teks, gambar serta video sangat membantu peserta didik dalam menguasai materi pembelajaran, terlebih lagi jika dilanjutkan dengan aktivitas praktik langsung seusai dengan contoh video yang ada pada media pembelajaran.

Atletik adalah olahraga paling tua dalam sejarah manusia, pada tahun 2.500 Sebelum Masehi (SM) bangsa Mesir Purba sudah mengenal olahraga lari sebagai bentuk perlombaan. Olahraga atletik dikenal dengan istilah the mother of sport atau induk dari segala cabang olahraga. Hampir semua cabang olahraga terkandung unsur gerak atletik seperti lari, lompat dan lempar.

Olahraga atletik terbagi menjadi beberapa nomor yaitu nomor lari, nomor lempar, dan nomor lompat. Menurut Muhajir (2017) Nomor lari Lari jarak pendek $(100 \mathrm{~m}, 200 \mathrm{~m}$, dan $400 \mathrm{~m})$; Lari jarak menengah $(800 \mathrm{~m}$, $1500 \mathrm{~m})$; Lari jarak jauh $(5000 \mathrm{~m}, 10.000 \mathrm{~m})$. Nomor lempar (lempar cakram, lempar lembing, tolak peluru, lontar martil); Nomor lompat (lompat jauh, lompat tinggi, lompat galah).

Nomor lari menjadi salah satu olahraga yang dipertandingan dari berbagai perlombaan atletik mulai dari tingkat pelajar sampai dewasa. Atletik nomor lari terdiri dari lari jarak pendek yang menempuh jarak 100 
meter, 200 meter, 400 meter serta nomor khusus lari estafet $4 \times 100$ meter. Jarak menengah yang menempuh jarak 800 meter, 1500 meter serta jarak jauh yang menempuh jarak 5000 meter, 10.000 meter dan lari Marathon.

Teknik dasar atau gerak spesifik nomor lari terdiri dari teknik start, teknik berlari dan teknik memasuki garis finish. Teknik start pada lari jarak pendek menggunakan start jongkok, sedangkan pada lari jarak menengah dan jarak jauh menggunakan start berdiri.

\section{B. Metode}

Metode yang digunakan yaitumetode Desain dan Pengembangan (Design and Development) yang artinyametode penelitian desain dan pengembangan dapat fokus pada pengembangan dan keefektifan suatu alat. Richey \& Klein (2009: 10).Tahap penelitian desain dan pengembangan di dalam Proccedings Penelitian Ellis \& Levy (2010), ada enam tahap dalam metode penelitian Desain dan Pengembangan yaitu: 1) Identifikasi masalah, 2) Menjelaskan tujuan, 3) Desain dan pengembangan alat, 4) Pengujian alat, 5) Evaluasi hasil pengujian, 6) Mengkomunikasikan hasil. Berikut ini gambar 6 tahap penelitian Desain dan Pengembangan:

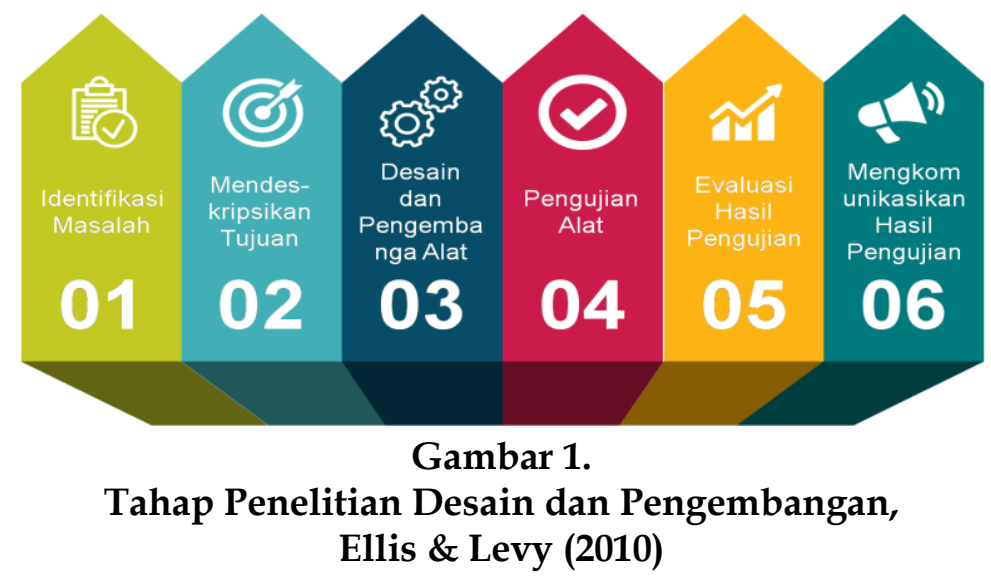

Berikut ini tahapan penelitian desain dan pengembangan aplikasi ANOLA untuk pembelajaran atletik nomor lari. 


\section{Identifikasi Masalah}

Penelitian dapat dilaksanakan apabila ditemukan permasalahan yang perlu diselesaikan, maka tahap identifikasi masalah menjadi bagian pertama pada penelitian D \& D ini. Melalui proses obsevasi dan evaluasi pada pembelajaran materi atletik nomor lari jarak pendek khususnya di kelas 8. Hasil penilaian ranah kognitif (KI. 3) pada materi atletik nomor lari jarak pendek lebih rendah dibandingkan nilai keterampilan (KI. 4), hal ini dikarenakan karaktersitik mata pelajaran PJOK yang lebih banyak melaksanakan aktivitas praktik dibandingkan pembelajaran teori, penyebab lainnya yaitu belum tersedia media pembelajaran yang dapat digunakan peserta didik untuk mempelajari materi agar lebih mendalam. Kegiatan literasi buku teks di awal pembelajaran ternyata kurang optimal dikarenakan cenderung monoton dan peserta didik lebih menyukai aktifitas praktik saat pembelajaran PJOK.

\section{Mendeskripsikan Tujuan}

Untuk mencari penyelesaian terhadap permasalahan terkait ketersediaan media pembelajaran yang dapat membantu peserta didik dalam mempelajari materi atletik nomor lari jarak pendek. Berdasarkan kajian teoritis dan hasil penelitian yang relevan, serta perkembangan teknologi informasi pada masa sekarang, maka media yang dikembangkan dapat berupa sebuah aplikasi yang dapat digunakan pada smartphone peserta didik.

\section{Desain dan Pengembangan Alat}

Tahapan desain dan pengembangan alat pada penelitian ini menggunakan model ADDIE (Analisys, Design, Development, Implementation, Evaluation). Aldoobie (2015) menyatakan bahwa model ADDIE merupakan salah satu model yang paling umum digunakan dalam bidang desain pengembangan bahan untuk pembelajaran. Penggunaan model ADDIE pada penelitian ini diharapkan dapat menghasilkan produk aplikasi yang efektif dan efisien. 


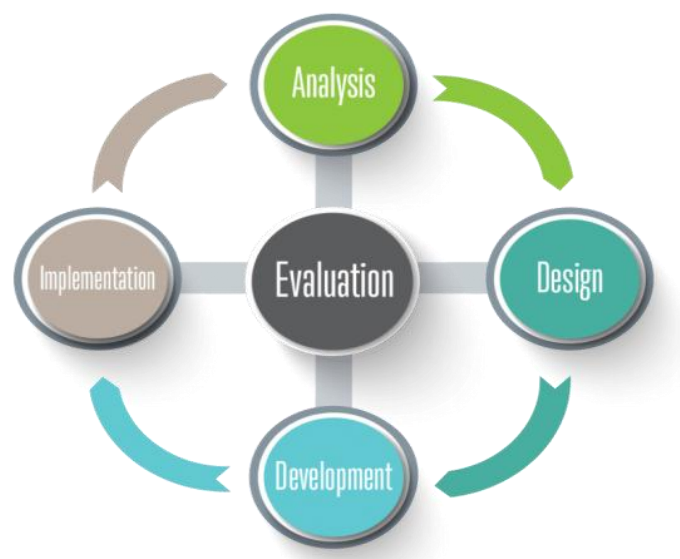

Gambar 2.

Siklus Desain dan Pengembangan Alat Model ADDIE

Berikut ini penerapan model ADDIE dalam desain pengembangan aplikasi $A N O L A$ untuk pembelajaran atletik nomor lari.

\section{a. Analisis}

Tahap ini merupakan tahap penting dalam pengembangan alat pembelajaran, analisis dilakukan untuk mengetahui kondisi peserta didik dan permasalahan yang dihadapi serta mencari alternatif penyelesaian masalah. Hasil inimenunjukan $80 \%$ peserta didik memiliki smartphone berbasis android sehingga untuk mengatasi rendahnya penguasaan ranah kognitif (KI.3) pada materi lari jarak pendek, maka perlu dikembangkan media pembelajaran berbasis android yang dapat digunakan oleh peserta didik untuk mempelajari materi lari jarak pendek secara kolektif maupun mandiri.

\section{b. Desain}

Seseorang dapat bertahan lama saat menggunakan smartphone yang didalamnya terdapat berbagai aplikasi yang menarik dan canggih. Hal tersebut menjadi motivasi dalam pengembangan aplikasi pembelajaran agar dirancang sedemikian rupa supaya peserta didik tertarik untuk menggunakannya.

Desain pengembangan media pembelajaran ini mengacu materi pembelajaran atletik kelas 8 yaitu nomor lari jarak pendek, agar pengembangan aplikasi pembelajaran dapat bermanfaat lebih luas, maka 
komponen yang masuk ke dalam aplikasi perlu ditambah materi lari jarak menengah dan lari jarak jauh. Hal ini dilakukan karena ketiga nomor lari tersebut saling berkaitan, sekaligus untuk meningkatkan wawasan peserta didik terhadap materi atletk nomor lari.

Agar aplikasi yang dikembangkan mudah dikenal dan mencerminkan isi dari aplikasi, maka peneliti memberi nama ANOLA yang merupakan akronim dari Atletik Nomor Lari. Sistem kerja pada aplikasi ANOLA saling terkait antara materi yang satu dengan materi yang lain, serta dirancang agar peserta didik sebagai pengguna dapat menggunakan aplikasi tersebut dengan mudah.

\section{c. Pengembangan}

Di era revolusi industri 4.0, berkembang teknologi yang memungkinkan seseorang saling terkoneksi untuk berbagi ilmu pengetahuan dan keterampilan. Hal ini menjadi dasar dalam pengembangan aplikasi ANOLA untuk menyediakan fasilitas literasi digital yang memfasilitasi peserta didik mendapatkan materi tambahan dari internet dan video pembelajaran melalui chanel Youtube, serta fasilitas tes online yang memudahkan peserta didik melaksanakan uji kompetensi secara mandiri di luar pembelajaran di sekolah.

\section{d. Implementasi}

Tahap implementasi aplikasi ANOLA untuk pembelajaran dilakukan dengan cara sosialisasi keberadaan aplikasi ANOLA yang dapat digunakan secara gratis untuk pembelajaran materi atletik nomor lari, kemudian dilanjutkan pelatihan penggunaan aplikasi ANOLA kepada perwakilan beberapa peserta didik yang nantinya akan dijadikan sebagai tutor teman sebaya dalam pemanfaatan aplikasi ANOLA untuk pembelajaran.

\section{e. Evaluasi}

Evaluasi dilakukan untuk mengetahui kekurangan dari aplikasi ANOLA, yang kemudian dilakukan perbaikan agar aplikasi tersebut dapat berjalan denga baik dan memberi manfaat bagi penggunanya. Proses 
evaluasi dilakukan dengan cara menerapkan aplikasi ANOLA pada smartphone peserta didik kemudian mengamati kinerja aplikasi dan penerapannya dalam pembelajaran materi atletik nomor lari.

\section{Pengujian Alat}

Tahap pengujian aplikasi ANOLA dilakukan melalui tiga cara yaitu oleh peneliti, oleh ahli media dan oleh peserta didik sebagai pengguna. Pengujian oleh peneliti dilakukan melaui Run Layout yang terdapat pada software Construct 2, serta menggunakan smartphone milik peneliti. Pengujian oleh ahli media, ahli materi dan peserta didik dilakukan untuk mengetahui tingkat kelayakan, kevalidan materi dan kepraktisan aplikasi ANOLA.

Instrumen uji kelayakan dan kepraktisan aplikasi ANOLA dilakukan dengan metode angket, kemudian data yang diperoleh dianalisis menggunakan analisis Deskripsi Persentase dengan langkahlangkah sebagai berikut:

a. Menghitung nilai responden dan masing-masing aspek atau sub variabel

b. Membuat tabulasi data

c. Menghitung nilai rata-rata

d. Menghitung persentase menggunakan rumus:

Keterangan:

$\mathrm{P}(\mathrm{s})=$ Persentase sub variabel $(\%)$

$\mathrm{S}=$ Jumlah skor yang diperoleh

$\mathrm{N}$ = Jumlah skor maksimum

Riduwan, (2013: 71)

e. Menentukan tingkat kriteria

1) Persentase Nilai tertinggi:

2) Persentase nilai terendah:

3) Menentukan rentang $=100-20=80$

4) Menentukan lebar interval = 
Tabel 1.

Rentang Persentase dan Kriteria Kelayakan

\begin{tabular}{rll}
\hline No & \multicolumn{1}{c}{ Interval } & \multicolumn{1}{c}{ Kriteria } \\
1 & $85 \% \leq$ Skor $\leq 100 \%$ & Sangat Layak \\
2 & $69 \% \leq$ Skor $\leq 84 \%$ & Layak \\
3 & $53 \% \leq$ Skor $\leq 68 \%$ & Kurang Layak \\
4 & $37 \% \leq$ Skor $\leq 52 \%$ & Tidak Layak \\
5 & $20 \% \leq$ Skor $\leq 36 \%$ & Sangat Tidak Layak \\
\hline
\end{tabular}

Tabel 2.

Rentang Persentase dan Kriteria Kepraktisan

\begin{tabular}{rll} 
No & \multicolumn{1}{c}{ Interval } & \multicolumn{1}{c}{ Kriteria } \\
1 & $85 \% \leq$ Skor $\leq 100 \%$ & Sangat Praktis \\
2 & $69 \% \leq$ Skor $\leq 84 \%$ & Praktis \\
3 & $53 \% \leq$ Skor $\leq 68 \%$ & Kurang Praktis \\
4 & $37 \% \leq$ Skor $\leq 52 \%$ & Tidak Praktis \\
5 & $20 \% \leq$ Skor $\leq 36 \%$ & Sangat Tidak Praktis \\
\hline
\end{tabular}

Tabel 3.

Rentang Persentase dan Kriteria Keefektifan

\begin{tabular}{lll}
\hline No & \multicolumn{1}{c}{ Interval } & \multicolumn{1}{c}{ Kriteria } \\
1 & $85 \% \leq$ Skor $\leq 100 \%$ & Sangat Efektif \\
2 & $69 \% \leq$ Skor $\leq 84 \%$ & Efektif \\
3 & $53 \% \leq$ Skor $\leq 68 \%$ & Kurang Efektif \\
4 & $37 \% \leq$ Skor $\leq 52 \%$ & Tidak Efektif \\
5 & $20 \% \leq$ Skor $\leq 36 \%$ & Sangat Tidak Efektif \\
\hline
\end{tabular}

Tabel 4.

Rentang Persentase dan Kriteria Kevalidan

\begin{tabular}{lll}
\hline No & Interval & Kriteria \\
1 & $85 \% \leq$ Skor $\leq 100 \%$ & Sangat Valid \\
2 & $69 \% \leq$ Skor $\leq 84 \%$ & Valid \\
3 & $53 \% \leq$ Skor $\leq 68 \%$ & Kurang Valid \\
4 & $37 \% \leq$ Skor $\leq 52 \%$ & Tidak Valid \\
5 & $20 \% \leq$ Skor $\leq 36 \%$ & Sangat Tidak Valid \\
\hline
\end{tabular}




\section{Evaluasi Hasil Pengujian Alat}

Data hasil pengujian alat menggunakan instrumen angket kemudian diolah dan dianalisis untuk mengetahui tingkat kepraktisan dan kepraktisan dari aplikasi ANOLA yang dikembangkan. Apabila masih terdapat kekurangan pada sistem kerja maupun isi materi aplikasi, maka akan dilakukan perbaikan kembali agar aplikasi dapat digunakan secara optimal dan sesuai dengan tujuan yang diharapkan.

\section{Mengkomunikasikan Hasil Uji Coba}

Hasil analisis pengujian alat kemudian dirumuskan menjadi sebuah kesimpulan yang merujuk pada rekomendasi untuk menggunakan aplikasi ANOLA berbasis android untuk dipergunakan sebagai media pembelajaran atletik nomor lari jarak pendek. Selanjutnya peneliti menyusun laporan dan mendesiminasikan aplikasi ANOLA kepada peserta didik, teman sejawat serta komunitas guru PJOK dalam kegiatan MGMP.

\section{Hasil dan Pembahasan}

Data hasil aplikasi praktis penggunaan aplikasi ANOLA dalam pembelajaran adalah sebagai berikut:

\section{Hasil Uji Kepraktisan dan Keefektifan Pengguna}

Uji kepraktisan dan keefektifan aplikasi ANOLA dilakukan dengan cara pengujian secara langsung kepada peserta didik sebagai pengguna. Pengujian dilakukan kepada 25 peserta didik kelas 8 D SMP Negeri 3 Bumijawa pada saat pembelajaran PJOK. Peserta didik mencoba aplikasi ANOLA secara langsung kemudian mengisi angket yang telah diberikan. Data hasil pengujian ditampilan pada tabel 5 berikut ini. 
Tabel 5.

Data Hasil Uji Kepraktisan dan Keefektifan

\begin{tabular}{|c|c|c|c|c|c|c|}
\hline \multirow{2}{*}{$\begin{array}{c}\text { No } \\
\text { Responden }\end{array}$} & \multicolumn{3}{|c|}{ Aspek Kepraktisan } & \multicolumn{3}{|c|}{ Aspek Keefektifan } \\
\hline & 1 & 2 & 3 & 4 & 5 & 6 \\
\hline 1 & $\overline{5}$ & $\overline{5}$ & 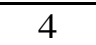 & $\overline{5}$ & $\overline{5}$ & $\overline{5}$ \\
\hline 2 & 4 & 5 & 5 & 4 & 4 & 5 \\
\hline 3 & 5 & 4 & 5 & 5 & 5 & 5 \\
\hline 4 & 5 & 4 & 5 & 5 & 4 & 4 \\
\hline 5 & 4 & 5 & 5 & 5 & 5 & 5 \\
\hline 6 & 5 & 5 & 5 & 5 & 5 & 5 \\
\hline 7 & 5 & 5 & 4 & 5 & 5 & 5 \\
\hline 8 & 4 & 5 & 4 & 5 & 4 & 5 \\
\hline 9 & 5 & 5 & 5 & 4 & 4 & 5 \\
\hline 10 & 5 & 5 & 5 & 4 & 4 & 5 \\
\hline 11 & 5 & 5 & 4 & 4 & 5 & 5 \\
\hline 12 & 5 & 5 & 4 & 5 & 5 & 5 \\
\hline 13 & 5 & 4 & 4 & 5 & 5 & 5 \\
\hline 14 & 5 & 5 & 4 & 5 & 5 & 5 \\
\hline 15 & 5 & 5 & 5 & 5 & 5 & 5 \\
\hline 16 & 4 & 5 & 4 & 5 & 5 & 5 \\
\hline 17 & 4 & 5 & 5 & 5 & 4 & 5 \\
\hline 18 & 5 & 5 & 5 & 4 & 5 & 5 \\
\hline 19 & 5 & 5 & 5 & 5 & 5 & 5 \\
\hline 20 & 5 & 5 & 5 & 5 & 5 & 5 \\
\hline 21 & 5 & 5 & 4 & 5 & 5 & 4 \\
\hline 22 & 5 & 5 & 5 & 5 & 5 & 5 \\
\hline 23 & 5 & 5 & 4 & 4 & 5 & 5 \\
\hline 24 & 5 & 5 & 4 & 5 & 5 & 5 \\
\hline 25 & 4 & 5 & 5 & 4 & 5 & 5 \\
\hline Jumlah & 119 & 122 & 114 & 118 & 119 & 123 \\
\hline Presentase & 95,2 & 97,6 & 91,2 & 94,4 & 95,2 & 98,4 \\
\hline $\begin{array}{c}\text { Rata-rata } \\
\text { Aspek }\end{array}$ & \multicolumn{3}{|c|}{94,67} & \multicolumn{3}{|c|}{96,00} \\
\hline
\end{tabular}


Berdasarkan rekapitulasi data penghitungan angket kepraktisan dan keefektifan aplikasi ANOLA diperoleh data persentase sebagai berikut:

a. Aspek Kepraktisan memperoleh hasil persentase $=94,67 \%$ (Sangat Praktis)

b. Aspek Keefektifan memperoleh hasil persentase $=96.00 \%$ (Sangat

\section{Efektif)}

Hasil analisis angket yang telah diisi oleh responden terdapat kritik dan saran yang diberikan, secara garis besar dapat disimpulkan sebagai berikut:

1) Kombinasi warna pada icon dibuat lebih menarik.

2) Perlu penambahan durasi video pembelajaran agar lebih lengkap.

\section{a. Hasil Uji Kevalidan Materi}

Uji kevalidan materi dilakukan oleh ketua MGMP PJOK SMP Kabupaten Tegal dan instruktur Kurikulum 2013 mata pelajaran PJOK SMP Kabupaten Tegal untuk menguji aspek isi materi yang terdapat pada aplikasi ANOLA. Berikut ini hasil uji kevalidan materi yang telah dilaksanakan.

Tabel 6.

Data Hasil Uji Kevalidan Materi

\begin{tabular}{|l|c|c|c|c|}
\hline \multirow{2}{*}{\multicolumn{1}{|c|}{ Nama Ahli }} & \multicolumn{4}{c|}{ Aspek Isi Materi } \\
\cline { 2 - 5 } & 1 & 2 & 3 & 4 \\
\hline \hline Drs. Winarna Budi Santosa & 5 & 5 & 5 & 5 \\
\hline Ari Purnomo, S.Pd & 5 & 5 & 5 & 5 \\
\hline Jumlah & 10 & 10 & 10 & 10 \\
\hline Persentase & $100 \%$ & $100 \%$ & $100 \%$ & $100 \%$ \\
\hline Rata-rata Aspek & \multicolumn{5}{|c|}{$100 \%$} \\
\hline
\end{tabular}

Berdasarkan hasil uji kevalidan materi oleh ahli materi dari ketua MGMP PJOK SMP Kabupaten Tegal Bapak Drs. Winarna Budi Santosa, dan Instruktur Kabupaten Kurikulum 2013 Bapak Ari Purnomo, S.Pd, 
maka dapat disimpulkan bahwa materi yang tersedia pada aplikasi ANOLA sebesar 100\% (Sangat Valid).

Saran yang diberikan oleh ahli materi untuk pengembangan lebih lanjut pada aplikasi ANOLA yaitu:

1) Materi yang disajikan lebih spesifik.

2) Soal uji kompetensi dibuat lebih variatif.

\section{b. Hasil Uji Kelayakan}

Uji Kelayakan aplikasi ANOLA dilakukan oleh ahli media yang berasal dari STKIP NU Slawi yaitu Bapak Ilham Susilo Bakti, M.Kom yang merupakan Ketua Jurusan sekaligus dosen Ilmu Komputer. Terdapat tiga aspek yang menjadi dasar kelayakan aplikasi ANOLA yaitu: aspek media, aspek tampilan visual dan aspek keefektifan aplikasi. Berikut ini data hasil uji kelayakan oleh ahli media.

\section{Tabel 7.}

\section{Data Hasil Uji Kelayakan Media}

\begin{tabular}{|l|c|c|c|c|c|c|c|}
\hline \multirow{2}{*}{ Nama Ahli } & \multicolumn{3}{|c|}{ Aspek Media } & \multicolumn{2}{c|}{$\begin{array}{c}\text { Aspek } \\
\text { Tampilan } \\
\text { Visual }\end{array}$} & $\begin{array}{c}\text { Aspek } \\
\text { Keefektifan } \\
\text { Aplikasi }\end{array}$ \\
\cline { 2 - 9 } & 1 & 2 & 3 & 4 & 5 & 6 & 7 \\
\hline \hline Ilham Susilo Bakti, M.Kom & 5 & 5 & 4 & 5 & 4 & 5 & 5 \\
\hline Jumlah & 5 & 5 & 4 & 5 & 4 & 5 & 5 \\
\hline Persentase & $100 \%$ & $100 \%$ & $80 \%$ & $100 \%$ & $80 \%$ & $100 \%$ & $100 \%$ \\
\hline Rata-rata Aspek & \multicolumn{3}{|c|}{$95 \%$} & \multicolumn{3}{c|}{$95 \%$} & $100 \%$ \\
\hline
\end{tabular}

Berdasarkan data di atas maka dapat disimpulkan rata-rata persentase kelayakan aplikasi ANOLA sebesar 96,67\% (Sangat Layak). Mesikpun hasil uji kelayakan oleh ahli media sangat positif, akan tetapi terdapat beberapa saran untuk pengembangan lebih lajut, diantaranya:

1) Perlu melengkapi materi di dalam aplikasi agar dalam penggunaan media tidak terlalu bergantung pada jaringan internet. 
2) Video pembelajaran yang tersedia dibuat lebih lengkap dan menarik.

\section{c. Data Persentase Ketuntasan Belajar}

Berikut ini persentase ketuntasan belajar klasikal ranah pengetahuan dan keterampilan melalui pre test dan post test.

\section{Tabel 8.}

Data Persentase Ketuntasan Belajar Klasikal Peserta Didik

\begin{tabular}{|c|l|c|c|}
\hline No & \multicolumn{1}{|c|}{ Jenis Tes } & Pre Test & $\begin{array}{c}\text { Post } \\
\text { Test }\end{array}$ \\
\hline 1 & $\begin{array}{l}\text { Persentase Ketutasan Belajar } \\
\text { Klasikal Ranah Pengetahuan (KI. } \\
3)\end{array}$ & $43 \%$ & $96 \%$ \\
\hline 2 & $\begin{array}{l}\text { Persentase Ketutasan Belajar } \\
\text { Klasikal Ranah Keterampilan } \\
(\text { KI. } 4)\end{array}$ & $63 \%$ & $86 \%$ \\
\hline
\end{tabular}

\section{Analisis Data Hasil Aplikasi Praktis Inovasi Pembelajaran}

Pada bagian ini akan dilakukan analisa terhadap data hasil angket yang telah diisi oleh respoden terhadap pengembangan aplikasi ANOLA berbasis android untuk pembelajaran PJOK materi lari jarak pendek.

a. Uji Kepraktisan dan Keefektifan

1) Uji Kepraktisan

Uji kepraktisan dilakukan untuk mengetahui tingkat kepraktisan dalam penggunaan aplikasi ANOLA, hal ini sangat penting agar aplikasi yang dikembangkan dapat dimanfaatkan untuk pembelajaran. Data hasil uji kepraktisan pada Tabel 2 menunjukan persentase yang cukup tinggi yaitu sebesar 94,67\% sehingga berdasarkan kriteria produk masuk dalam kategori "Sangat Praktis". Hal ini sesuai dengan teori penelitian desain dan pengembangan menurut Richey \& Klein (2007) dimana metode 
penelitian desain dan pengembangan digunakan untuk menguji teori dan kepraktisan suatu alat atau produk.

\section{2) Uji Keefektifan}

Uji keefektifan dilakukan untuk mengetahui seberapa Praktis penggunaan aplikasi ANOLA dalam meningkatkan pengetahuan (KI.3) peserta didik khususnya pada materi lari jarak pendek. Hasil analisis data pada Tabel 2 diperoleh angka presentase keefektifan aplikasi ANOLA sebesar 96\% sehingga berdasarkan kriteria produk masuk dalam kategori "Sangat Efektif". Pengembangan aplikasi menggunakan model ADDIE (Analisys, Design, Development, Implementation, Evaluation), bertujuan untuk mendapatkan produk aplikasi yang efektif dan efisien (Aldoobie, 2015).

Berdasarkan analisis di atas maka dapat disimpulkan bahwa aplikasi ANOLA berbasis android dapat dipergunakan untuk pembelajaran materi atletik nomor lari jarak pendek baik di dalam kegiatan belajar mengajar maupun di luar kegiatan belajar mengajar, karena mudah digunakan, praktis, gratis, dan Praktis untuk meningkatkan pengetahuan peserta didik dalam pembelajaran materi atletik nomor lari jarak pendek.

b. Uji Kevalidan Materi

Uji kevalidan materi dilakukan untuk memastikan bahwa materi pembelajaran yang ada pada aplikasi ANOLA sesuai dengan Kurikulum 2013. Instrumen untuk menguji kevalidan materi menggunakan angket uji materi yang telah disusun sesuai dengan kebutuhan. Berdasarkan hasil uji kevalidan materi oleh ahli materi Bapak Drs. Winarno Budi Santosa diperoleh angka maksimum yaitu 100\% (Sangat Valid). Pengujian materi oleh ahli materi dilakukan dengan cara mengecek kesesuaian materi pada aplikasi ANOLA dengan silabus, RPP dan buku teks Kurikulum 2013.

Meskipun dinyatakan valid $100 \%$ namun ahli materi memberikan saran agar isi materi pada aplikasi ANOLA dikembangkan lagi dengan 
memanfaatkan literasi teknologi berupa media internet yang lebih luas. Hal ini bertujuan agar peserta didik senantiasa mengikuti perkembangan ilmu pengetahuan yang setiap saat terus berjalan.

1) Uji Kelayakan Media

Uji kelayakan media dilakukan untuk menguji kelayakan aplikasi ANOLA sebelum digunakan secara luas dalam pembelajaran. Hasil uji kelayakan media pada Tabel 4 menunjukan bahwa rata-rata persentase kelayakan aplikasi ANOLA sebesar 96,67\% (Sangat Layak). Kelayakan sebuah aplikasi atau media pembelajaran didasarkan pada tiga aspek yaitu: media, tampilan visual dan keefektifan aplikasi. Selain berdasarkan data kuantitatifyaitu jumlah persentase kelayakan di atas, ahli media juga memberikan rekomendasi bahwa aplikasi ANOLA berbasis android layak untuk digunakan dalam pembelajaran.

2) Ketuntasan Belajar Klasikal Peserta Didik

Sebagaimana dibahas pada bab sebelumnya, bahwa pengembangan aplikasi ANOLA diharapkan dapat bermanfaat untuk meningkatkan pengetahuan (KI. 3) dan keterampilan (KI.4) peserta didik. Hasil uji kompetensi terhadap 30 peserta didik dari kelas $8 \mathrm{D}$ menunjukan adanya peningkatan ketuntasan belajar klasikal pada ranah pengetahuan dan keterampilan yang ditampilkan pada Tabel 8. Persentase ketuntasan belajar klasikal pada ranah pengetahuan (KI. 3) saat pre test sebesar $43 \%$, setelah melaksanakan pembelajaran menggunakan aplikasi ANOLA kemudian dilaksanakan post test ternyata meningkat menjadi 96\%. Sedangkan pada ranah keterampilan (KI. 4), ketuntasan belajar klasikal pada saat pre test sebesar $63 \%$ kemudian setelah dilakukan post test meningkat menjadi $86 \%$.

Peningkatan ketuntasan belajar secara klasikal menggambarkan adanya peningkatan hasil belajar peserta didik secara individu, sehingga dapat disimpulkan bahwa pengembangan aplikasi ANOLA berdampak positif terhadap peningkatan hasil belajar peserta didik pada materi atletik nomor lari jarak pendek. 
Fitur belajar yang tersedia pada aplikasi ANOLA terdiri dari teks, gambar dan video pembelajaran, berdasarkan teori pengalaman belajar Edgar Dale yang dikenal dengan Cone Of Experience, maka pada aplikasi ANOLA sudah memenuhi tingkat keterlibatan belajar dari tingkatan verbal (10\% yang diingat), dan visual (30\% yang diingat). Sedangkan pada aktivitas praktik pembelajaran lari jarak pendek dengan mencoba gerakan sesuai dengan video pembelajaran yang terdapat pada aplikasi ANOLA, maka peserta didik memiliki peluang 90\% mengingat materi pembelajaran lari jarak pendek secara optimal.

\section{Penutup}

Berdasarkan hasil pembahasan dapat disimpulkan sebagai pengembangan aplikasi ANOLA berbasis android untuk pembelajaran atletik nomor lari jarak pendek menggunakan metode penelitian Design and Development $(D \& D)$ dan model pengembangan aplikasi yang digunakan yaitu model ADDIE (Analisys, Design, Development, Implementation, Evaluation).

Hasil uji kepraktisan aplikasi ANOLA diperoleh angka 94,67 (Sangat Praktis) sedangkan uji keefektifan aplikasi ANOLA diperoleh angka 96\% (Sangat Efektif) sehingga aplikasi ANOLA dapat dipergunakan oleh peserta didik sebagai media pembelajaran yang efektif dan efisien.Sedangkan hasil uji kelayakan aplikasi ANOLA diperoleh angka 96,67\% (Sangat Layak), sehingga aplikasi ini layak digunakan oleh peserta didik dalam pembelajaran materi atletik nomor lari jarak pendek. Dan persentase ketuntasan belajar klasikal pada ranah pengetahuan (KI. 3) saat pre test sebesar $43 \%$, setelah melaksanakan pembelajaran menggunakan aplikasi ANOLA hasil post test meningkat menjadi 96\%. Sedangkan pada ranah keterampilan (KI. 4), ketuntasan belajar klasikal pada saat pre test sebesar $63 \%$ dan post test meningkat menjadi $86 \%$. 


\section{Ucapan Terimakasih}

Ucapan terima kasih kepada Keluarga Besar SMP Negeri 3 Bumijawa yang telah mendukung proses penelitian dan Pemerintah Kabupaten Tegal melalui Dinas Dikbud yang senantiasa memberikan arahan dan dukungan dalam pengembangan aplikasi ANOLA.

\section{Daftar Referensi}

Aldoobi e Nada. (2015). ADDIE Model. American International Journal of Contemporary Research Vol. 5, No. 6; December 2015. Diunduh 12 Juni 2019.

EllisTimothy J \& Levy Yair. (2010). A Guide for Novice Researchers: Design and Development Research Methods. Proceedings of Informing Science \& IT Education Conference (InSITE). Diakses dari:

http:// proceedings.informingscience.org/InSITE2010/InSITE10p1 07-118Ellis725.pdf. Diunduh 14 Juli 2019.

Idris, S., \& Tabrani ZA. (2017). Realitas Konsep Pendidikan Humanisme dalam Konteks Pendidikan Islam. Jurnal Edukasi: Jurnal Bimbingan Konseling, 3(1), 96-113. https:/ / doi.org/10.22373/je.v3i1.1420

Khanna P. \& Singh A. (2016). Google Android Operating System: A Review. International Journal Of Computer Applications. 09758887. Volume 147-no.4 August 2016. Diakses dari: https:/ / pdfs.semanticscholar.org /2517/699bbd70ac347007127e038b99cc85928910.pdf. Diunduh 14 Juli 2019.

Kusyaeri Destia. (2017). Pengaruh Mobile Learning Berbasis Android Terhadap Hasil Belajar Siswa Pada Konsep Dinamika Partikel. (online). Diakses dari: http://repository.uinjkt.ac.id/dspace/ bitstream/ 1234567 89/36454/1/Destia-FITK. Diunduh 14 Juli 2019.

Moradman Nasir. (2014). The Design and Implementation of an Educational Multimedia Mathematics Software: Using ADDIE to Guide Instructional System Design. The Journal of Applied Instructional Design. Volume 4 Issue Oktober 2014. ISSN: 21605289 . 
https://pdfs.semanticscholar.org/082d/f7721612aeab36291b0928f abf8091b87dd5.pdf. Diunduh 12 Juni 2019.

Muhajir. (2017). Pendidikan Jasmani, Olahraga, dan Kesehatan. Jakarta: Puskurbuk, Balitbang Kemdikbud.

Muklis. (2009). Olahraga Kegemaranku Atletik. Jakarta : Intan Pariwara.

Pamela, C., Villalobosl, L., \& Peralta, N. (2017). Difference Cultural

Structure and Behavior Students in Learning Process. Jurnal Ilmiah

Peuradeun, 5(1), 15-24. doi:10.26811/ peuradeun.v5i1.115

Pamungkas H.S. (2018). Pengembangan Aplikasi Edukatif Berbasis Android Sebagai Media Pembelajaran Akuntansi. (online). Diakses dari: http://eprints.ums.ac.id/70157/18/naspub.pdf. Diunduh 12 Juni 2019.

Richey, R. C., \& Klein, J. D. (2009). Design and Development Research. Mahwah, NJ: Lawrence Erlbaum Associates, Publishers.Diunduh 12 Juni 2019.

Riduwan. (2013). Rumus dan Data dalam Analisis Statistika. Bandung: Alfabeta.

Sari. (2019). Analisis Terhadap Kerucut Pengalaman Edgar Dale dan Keragaman Gaya Belajar untuk Memilih Media yang Tepat dalam Pembelajaran. dalam Jurnal Manajemen Pendidikan, Vol. 1 No.1. ISSN: 2655-9331.

Siswanto, R., Sugiono, S., \& Prasojo, L. (2018). The Development of Management Model Program of Vocational School Teacher Partnership with Business World and Industry Word (DUDI). Jurnal Ilmiah Peuradeun, 6(3), 365-384. doi:10.26811/peuradeun.v6i3.322

Tabrani ZA. (2011). Dynamics of Political System of Education Indonesia. International Journal of Democracy, 17(2), 99-113.

Tabrani ZA. (2012). Future Life of Islamic Education in Indonesia. International Journal of Democracy, 18(2), 271-284.

Tabrani ZA. (2013). Kebijakan Pemerintah dalam Pengelolaan Satuan Pendidikan Keagamaan Islam (Tantangan Terhadap Implementasi Manajemen Berbasis Sekolah). Serambi Tarbawi, 1(2), 65-84.

www.jabar.tribunnews.com. 
Vol. 4, No. 2, Juli 2020 